\title{
Characterizing Computational Thinking for Tertiary Education Learning
}

\author{
Salman Firdaus Sidek*, Maizatul Hayati Mohamad Yatim \& Che Soh Said \\ Faculty of Art, Computing and Creative Industry, \\ Sultan Idris Education University, Perak Malaysia \\ Email:salmanfirdaus@fskik.upsi.edu.my \\ DOI: https://doi.org/10.37134/jcit.vol10.sp.6.2020
}

Cite this paper (APA): Sidek, S. F., Mohamad Yatim, M. H., \& Said, C. S. (2020). Characterizing Computational Thinking for Tertiary Education Learning. Journal of Contemporary Issues and Thought, 10, 58-69. https://doi.org/10.37134/jcit.vol10.sp.6.2020

\begin{abstract}
As the term computational thinking was just introduced into Malaysian education landscape in early 2017, the knowledge about it is still limited. Therefore, a literature review mapping has been done in order to identify its features and global research pattern related to this skill. IEEEXplore, Science Direct, and Web of Science were selected as the main sources of the articles out of 13 other repositories. The total of 325 articles were found by using computational thinking with punctuation marks " " as keywords via selected repositories. Out of this total, 109 articles have met the criteria and only 86 articles were referred together with another 30 additional multitype references. Finally, 66 features were generated from 29 referred articles related to the characterization of computational thinking skill. Among these features, three with the highest frequency were identified. It made up of two features that often assessed at tertiary education level namely algorithm and abstraction as well as two other features that are said as the true essence of the skill namely abstraction and decomposition with one of them is overlapped. Therefore, these three features are suggested to be in the list of variables of any research related to tertiary education learning.
\end{abstract}

Keywords: Abstraction; Algorithm; Computational Thinking; Decomposition; Tertiary Education

\section{Introduction}

In 1980, an American-South African Mathematician named Seymour Papert attempted to cultivate a computational environment in people's life. One of the approaches was using computational idea and technology as learning and thinking tools that emotionally and cognitively evolve (Papert, 1980). Of the 24 words related to 'computational' found in Mindstorms by Papert, the term 'computational thinking' has appeared once for the first time in history through the script. In that regard, Kong and Wong (2017), Lugo et al. (2018) and Shute et al. (2017) agreed that this term is based on Papert's work.

This term gained the attention of many researchers when a seminal article written by Wing emphasised that computational thinking skill should not only be acquired by computer scientist but it is a fundamental skill that every individual must possess similar as reading, writing and arithmetic skills (Li, 2016; Wing, 2006). This is due to the growing role of computer technology in daily routine especially in helping people to solve problems in the 21st century (Wing, 2006). Wing's argument has made a huge impact on education across the world, in countries such as Australia, England, Estonia, Finland, New Zealand, Norway, Sweden, South 
Korea, Poland, and United States have been or are taking the initiative to apply computational thinking skill in their educational curriculum since 2011 (Heintz et al. 2016). It encompasses effort to cultivate computational thinking among pupils, students, and teachers at national level through a variety of K-12 education curriculum models and also programmes for inservice teachers.

In the Malaysian education landscape, reading, writing and arithmetic skills have been disseminated through the Primary School New Curriculum (KBSR) since 1983. A few years later, the Primary School Standard Curriculum (KSSR) which was implemented gradually starting 2011 and replaced by the revised version of Primary School Standard Curriculum (KSSR) in 2017 that started to incorporate thinking skills specifically focused on reasoning and high order thinking skills (HOTS) into primary school curriculum besides the existing reading, writing and arithmetic skills. The wave of 'computational thinking for everyone' (National Research Council [NRC], 2010) also had its impact to the Ministry of Education Malaysia (MOE) after they realized the importance of computational thinking as a fundamental thinking skill based on technology that is needed in order to solve life routine's problems in the future (Curriculum Development Division [BPK], 2015). In this regard, MOE has taken the initiative to emphasise this skill especially among lower secondary pupils through the implementation of the Secondary School Standard Curriculum (KSSM), Dini Integrated Curriculum (KBD) and Tahfiz Integrated Curriculum (KBT) starting 2017.

Through the new Fundamental of Computer Science (ASK) subject for Form 1 or 13 years old secondary school pupils, four techniques considered as the basis of computational thinking skills are introduced, namely decomposition, pattern recognition, abstraction, and generalization. Scratch and HTML programming software has been used as the tools to convey knowledge and skill of computational thinking through various activities such as algorithm and computer program development according to ASK textbook and ASK Teaching and Learning module. In the context of teachers, Teacher Education Division (BPG) has organized Form 1 Computer Science Teacher Training Programme while the My Digital Maker Programme was launched in 2016 in collaboration with MOE and Malaysia Digital Economy Corporation Sdn. Bhd. (MDEC) was also targeting in-service teachers who will teach ASK and Computer Science (SK) subjects recently introduced in schools.

\section{Statement of the Problem}

In this context, it was clear that the authority has executed continuous effort in order to develop strong thinking skills through KBSR and KSSR implementation in school levels, as well as KSSM which focused on computational thinking skills. This effort also involved special programmes for in-service teachers which also specifically focused on computational thinking skills. However, the computational thinking skills were acquired by a small number of pupils because ASK subject is offered for a certain group of pupils, who choose to take the subject with the approval of school administration, even though it has been listed as compulsory subject as stated in the Ministry of Education's Ikhtisas Circular Letter Number 9 Year 2016 (MOE, 2017). Same goes to in-service teachers where only those appointed to teach ASK and Computer Science (SK) subjects recently introduced in schools were directed to join computational thinking workshops organized by the responsible parties. Both of these situations do not help in realizing computational thinking as a fundamental skill that each individual should possess similar to reading, writing, and arithmetic skills, as stated by Wing (2006). 
At the same time, education at the tertiary level also does not specifically emphasise on the importance of computational thinking skills. On the other hand, HOTS become solid focus across various courses in many years. A preliminary survey conducted randomly among 50 respondents from 21 multiple fields of educational programmes offered by 9 faculties at Sultan Idris Education University (UPSI) which was conducted in early 2019 shows that up to $92 \%$ of respondents were not aware of computational thinking skills. While on the other hand, $94 \%$ of respondents agreed that they must have thinking skill in a computational way before facing the challenges of teaching in schools in the 21st century. This condition has potential to thwart the continuous efforts of the government through the implementation of KBSR, KSSR, KSSM, and in-service teacher programmes on the basis of students of the educational programme are potential teachers in the future and a catalyst to the ongoing effort that has been initiated by the government. Moreover, it also did not support Wing (2006) and National Research Council (2010) recommendation of 'computational thinking for everyone' and indirectly will cause Malaysians to fall behind in thinking skills.

Given that much of the effort is only focused on a small group of students in schools and in-service teachers, research on learning at tertiary education level especially involving students from education programmes should be undertaken. Due to the computational thinking is relatively to a new term in Malaysia especially in the field of tertiary education, the features of this term must be well understood before further steps can be taken in order to identify existing research gaps and determine the direction of the related research.

\section{Methodology and Data Collection}

According to Toedte and Aydeniz (2015), the Web of Science (WoS) and Wiley Online Library (Wiley) are two common repositories of academic writing, while the Association for Computing Machinery digital library (ACM) is a specific repository for computing and the Institute for Electrical and Electronics Engineers digital library (IEEEXplore) is generally technology-focused repository (Toedte \& Aydeniz, 2015). 17 articles from WoS, 4 articles from IEEEXplore and 20 articles from ACM that related to computational thinking and its impact on K-12 science education have been found through these repositories by Toedte and Aydeniz (2015). Currently, the searching process has been simplified as IEEEXplore also facilitates searching through Wiley.

Earlier, 27 intervention studies that met the criteria related to the development of computational thinking through programming platform and its implication on research and teaching have been found from the ERIC database and the Social Sciences Citation Index (SSCI) by Lye and Koh (2014). Currently, the searching process through SSCI also has been simplified via service offered by WoS. Meanwhile, 27 articles related to computational thinking ability assessment have been found through ACM, ERIC, IEEEXplore, Science Direct (SD), Springer, and Scopus by de Araujo et al. (2016). These repositories were selected as they are considered as main sources for articles related to Computer Science and Education (de Araujo et al., 2016). Besides, 45 out of 70 articles that met the criteria related to computational thinking definitions, interventions, assessments and models have been found through ERIC, PsycINFO, JSTOR, and Google Scholar databases by Shute et al. (2017). While Silva et al. (2018) have found 15 articles that met the criteria out of an initial volume of 712 articles related to the study on the impact of teaching approaches on computational thinking of upper secondary pupils through six repositories namely ACM, El Compendex, IEEEXplore, WoS, SD, and 
Scopus. However, Shute et al. (2017) and Silva et al. (2018) did not state any justification for the selection of such repositories.

Based on Fig. 1, ERIC, ACM, and IEEEXplore are the top options by researchers. Therefore, one of the repositories will be used to find out articles for this research. At the same time, two other repositories that popular among researchers, WoS and SD are also used in this research. Both repositories are selected because they are common repositories of academic writing (Toedte \& Aydeniz, 2015) and also one of the leading repositories for publications related to Computer Science and Education (de Araujo et al., 2016).

As the new term of computational thinking emerged in the Malaysian education landscape in early 2017, the knowledge about it is still limited. There are only four official resources or references found namely the Fundamental of Computer Science for Form 1 textbook and the Fundamental of Computer Science for Form 1 Teaching and Learning Module published for MOE in 2016, the Fundamental of Computer Science for Form 1 Module produced by Teacher Education Division (BPG) in 2016 for the Teacher Training Programme and the Computational Thinking and Computer Science Teaching Certification Module produced by MDEC for the My Digital Maker Programme 2016 which was the collaboration programme with MOE in order to train in-service teachers who are teaching ASK and SK subjects, which was introduced recently in school. Therefore, the search through selected repositories was generally intended to identify the characters of computational thinking skills and to find out the extent of the computational thinking field has been the aim of any local and international researches.

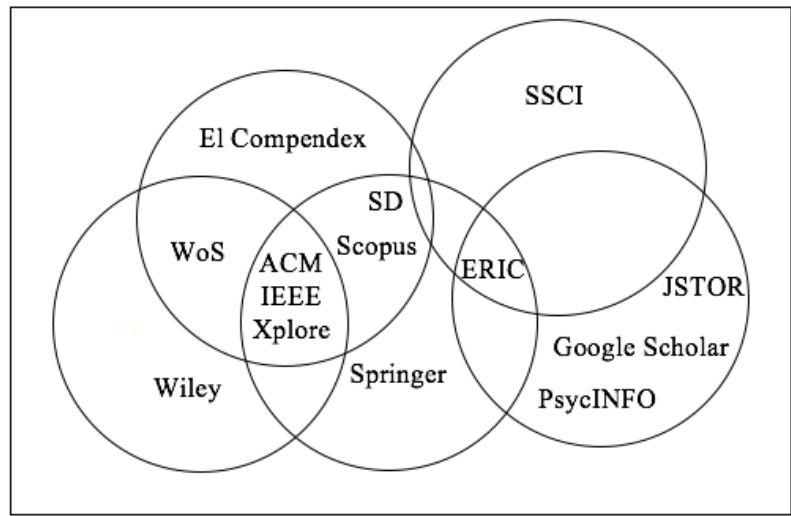

Figure 1 Venn Diagram showing 13 repositories used by the researchers as stated

Document search by keyword computational thinking in abstracts, document title, and publication title via IEEEXplore and Wiley from 2014 to March 2018 has found 39 journal and magazine-type documents. The analysis of these 39 documents showed that only 12 documents met the required criteria, whether related to computational thinking in education in general, curriculum, pedagogy, learning and assessment or related to definition and concept of computational thinking. However, document search by keyword computational thinking with punctuation marks " and " has found 12 journal and magazine-type documents. Out of this amount, 11 documents has met the required criteria and all of them were overlap with 11 other documents obtained from the analysis of previous 39 documents. This searching proved that using computational thinking as a keyword together with punctuation marks " and "would result more accurate documents. Therefore, the next document search through IEEEXplore and Wiley by keyword computational thinking and punctuation marks " and " has found 167 
conference papers related to computational thinking. 52 of them were discarded because of non-English papers, overlapped with previous document search, keynote papers, abstract, and also touch a very small part of computational thinking. Out of the remaining 115 conference papers, 58 papers has met the required criteria while the other 57 papers were used as additional reading resources. In overall, out of 70 papers that met the criteria, only 47 papers were referred to in this research.

Document search made through SD by title or abstract, or keyword containing computational thinking with punctuation marks " and " has found 58 documents including review articles, research articles and editorials for a period of five years from 2014 to March 2018. The abstracts of these documents have been analyzed and only 17 documents have met the required criteria which include computational thinking in education in general, curriculum, pedagogy, learning, and assessment or related to the definition and concept of computational thinking. All of these article documents were referred to in this research. The articles either contain 'computational science' term or do not focus on computational thinking were also removed from the list of documents for reference.

Document search by keyword "computational thinking" in topic or title through WoS has found 61 article-type documents from 2014 to March 2018 from multiples resources including ACM, Taylor \& Francis and Springer. Out of this total, 22 have met the criteria and referred in this research.

Additionally, about 30 other documents from internet webpage, books, and workshop's reports were also referred based on their relevance to this research. Table I shows the number of documents found from those selected resources.

Table 1: The number of articles/documents found from selected resources

\begin{tabular}{|c|c|c|c|c|c|c|c|}
\hline Resource & Keyword & $\begin{array}{l}\text { Searching } \\
\text { Method }\end{array}$ & Year & $\begin{array}{l}\text { Document } \\
\text { Type }\end{array}$ & $\begin{array}{c}\text { No. of } \\
\text { Articles }\end{array}$ & $\begin{array}{l}\text { No. of } \\
\text { Articles } \\
\text { Met The } \\
\text { Criteria }\end{array}$ & $\begin{array}{c}\text { No. of } \\
\text { References }\end{array}$ \\
\hline $\begin{array}{l}\text { IEEEXplore } \\
\text { and Wiley }\end{array}$ & $\begin{array}{l}\text { computational } \\
\text { thinking }\end{array}$ & $\begin{array}{l}\text { abstract, } \\
\text { document } \\
\text { title, and } \\
\text { publication } \\
\text { title }\end{array}$ & $\begin{array}{c}2014 \text { - } \\
\text { March } \\
2018\end{array}$ & $\begin{array}{l}\text { Journal and } \\
\text { magazine }\end{array}$ & 39 & 12 & \\
\hline $\begin{array}{l}\text { IEEEXplore } \\
\text { and Wiley }\end{array}$ & $\begin{array}{l}\text { "computational } \\
\text { thinking" }\end{array}$ & $\begin{array}{l}\text { abstract, } \\
\text { document } \\
\text { title, and } \\
\text { publication } \\
\text { title }\end{array}$ & $\begin{array}{c}2014- \\
\text { March } \\
2018\end{array}$ & $\begin{array}{l}\text { Journal and } \\
\text { magazine }\end{array}$ & 11 & 11 & 47 \\
\hline $\begin{array}{l}\text { IEEEXplore } \\
\text { and Wiley }\end{array}$ & $\begin{array}{l}\text { "computational } \\
\text { thinking" }\end{array}$ & $\begin{array}{l}\text { abstract, } \\
\text { document } \\
\text { title, and } \\
\text { publication } \\
\text { title }\end{array}$ & $\begin{array}{c}2014 \text { - } \\
\text { March } \\
2018\end{array}$ & $\begin{array}{c}\text { Conference } \\
\text { paper }\end{array}$ & 167 & 58 & \\
\hline $\begin{array}{l}\text { Science } \\
\text { Direct }\end{array}$ & $\begin{array}{l}\text { "computational } \\
\text { thinking" }\end{array}$ & $\begin{array}{c}\text { title or } \\
\text { abstract, or } \\
\text { keyword }\end{array}$ & $\begin{array}{c}2014 \text { - } \\
\text { March } \\
2018\end{array}$ & $\begin{array}{c}\text { Literature } \\
\text { article, } \\
\text { research } \\
\text { article }\end{array}$ & 58 & 17 & 17 \\
\hline WoS & $\begin{array}{l}\text { "computational } \\
\text { thinking" }\end{array}$ & topic or title & $\begin{array}{c}2014 \text { - } \\
\text { March } \\
2018\end{array}$ & Article & 61 & 22 & 22 \\
\hline Other & - & - & - & $\begin{array}{c}\text { Internet } \\
\text { webpage, } \\
\text { books, } \\
\text { workshop's } \\
\text { report }\end{array}$ & - & $>30$ & $>30$ \\
\hline
\end{tabular}




\section{Results}

After these 116 articles and documents were analysed in detailed, it was found that only 29 references related to the characterisation of computational thinking. The characterisation was referred to the features or elements that characterise computational thinking derived from these 29 references as shown in Table 2. Based on the table, 66 elements were found and among these elements, abstraction and algorithm seem to get a lot of attention from researchers where its frequency represents $9.87 \%$ and $7.41 \%$ out of overall 243 times these 66 elements became subjects of researches. Even though the percentage is acquired from the combination of K-12 and tertiary education level but it also clearly supports Sondakh (2018) who argues that algorithm and abstraction are two elements of computational thinking skills that are often assessed at the higher education level.

Furthermore, decomposition which represents $5.35 \%$ is the third-highest frequency of element that often becomes subject of researches. This finding supports Wing (2006) and Turchi and Malizia (2016) which argued that abstraction and decomposition are often become the focus and already reached a consensus among researchers. Same goes to Ota et al. (2016) who argued that abstraction and decomposition are the true essence of computational thinking skills because they are two out of three most important competencies to convert the real-world problems into computer programming.

The findings that supported by those references are as expected because abstraction, algorithm, and decomposition, as well as generalisation are among 20 elements of computational thinking that were acknowledged useful when an individual understands and knows how to apply them in multiple contexts (Burke et al., 2019). Even in tertiary education learning, Yadav et al. (2011) and Yadav et al. (2014) also focused on abstraction, algorithm, and decomposition which cover three out of five elements of computational thinking to be implemented through education courses for students of the educational programme and preservice teachers.

Therefore, based on the findings from the systematic literature review as showed in Table 2 that consistent with Sondakh's (2018) and research execution by Yadav et. al (2011) and Yadav et. al (2014), both are focused on tertiary education learning. Three elements with highest frequency as listed in Table 2 which also represents the most commonly used computational thinking elements in global researches will be set up as dependent variables for the research. Those elements are abstraction, algorithm, and decomposition, with additional element, namely generalisation.

Table 2: The 66 elements characterize computational thinking skills 


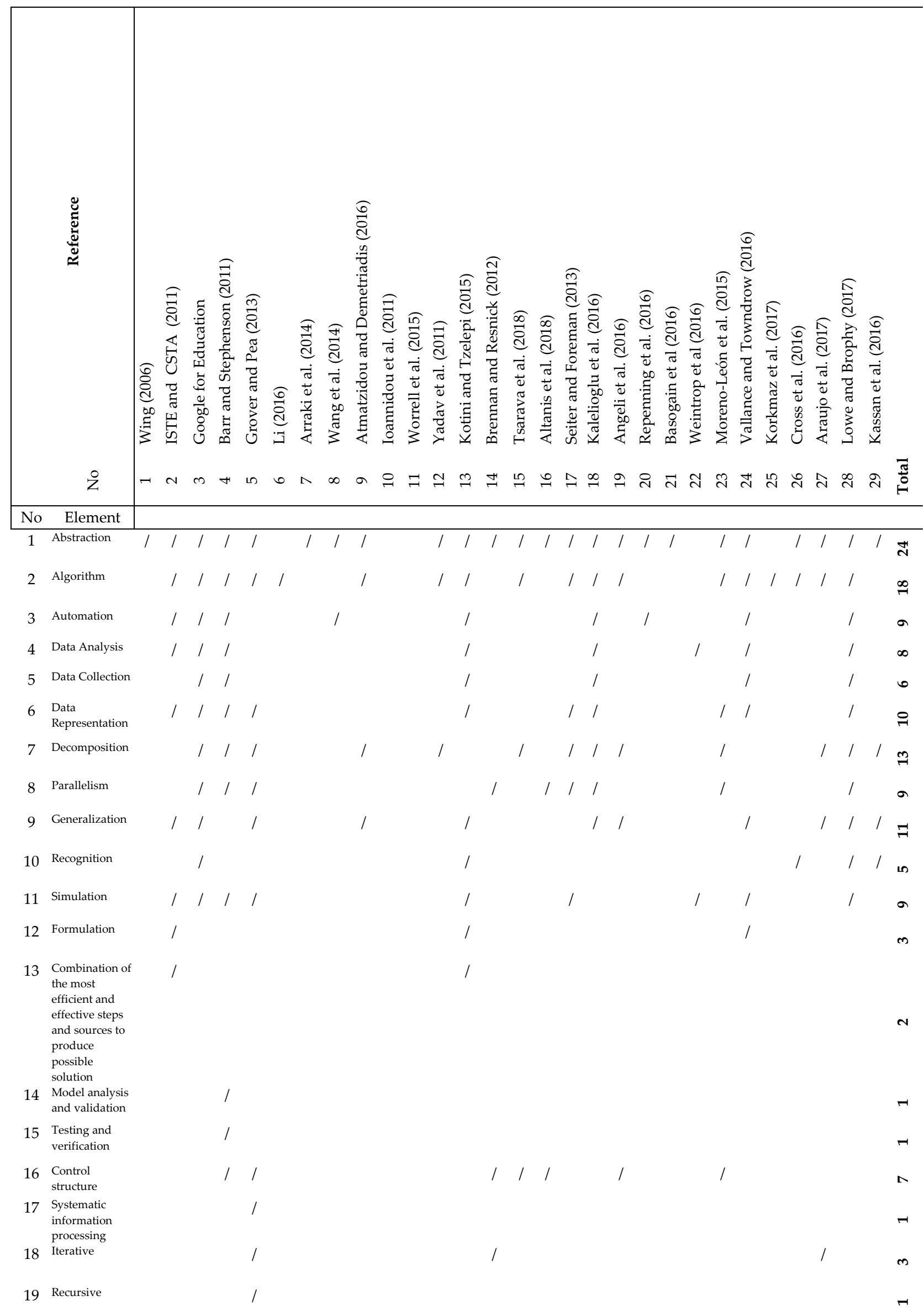




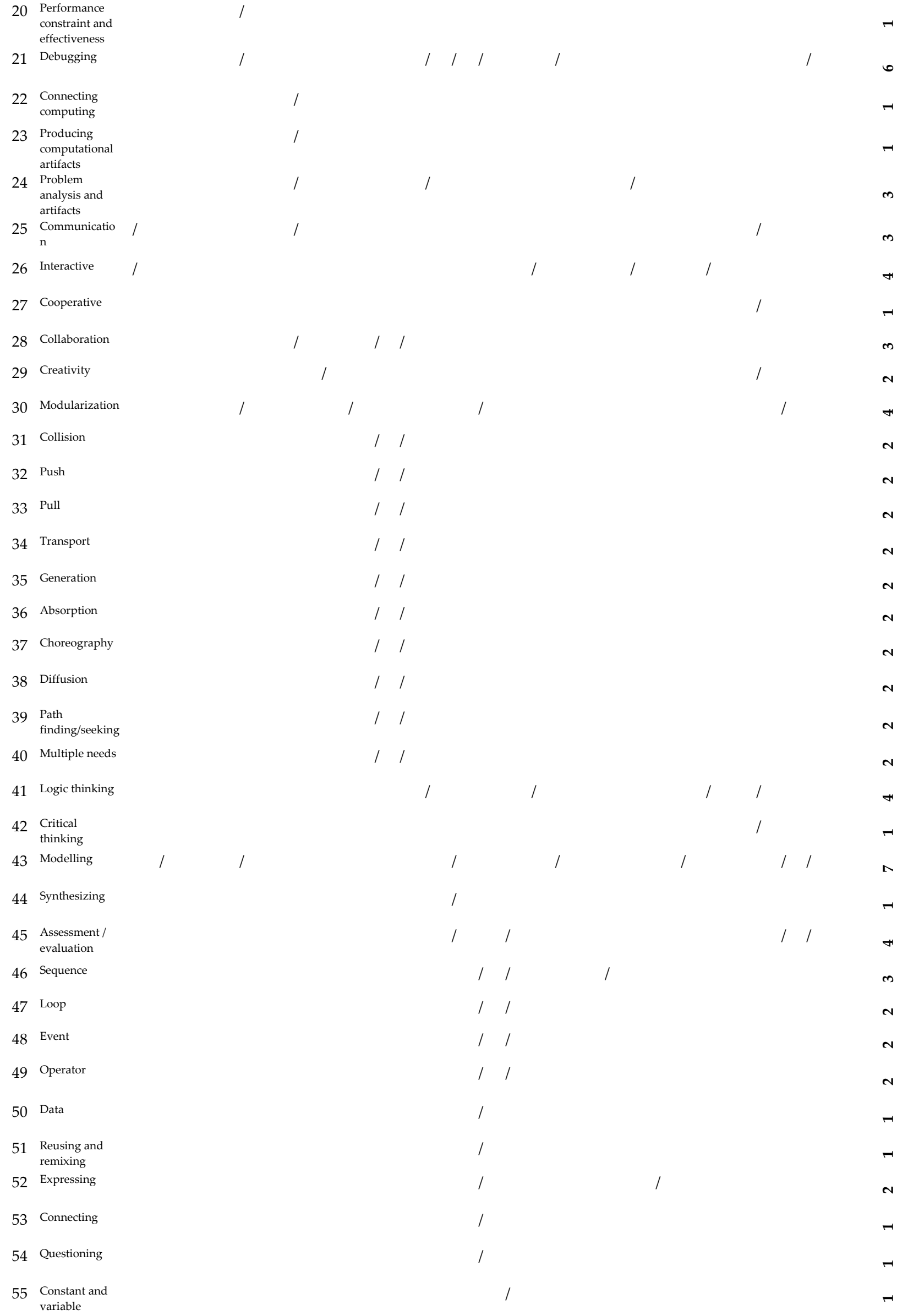




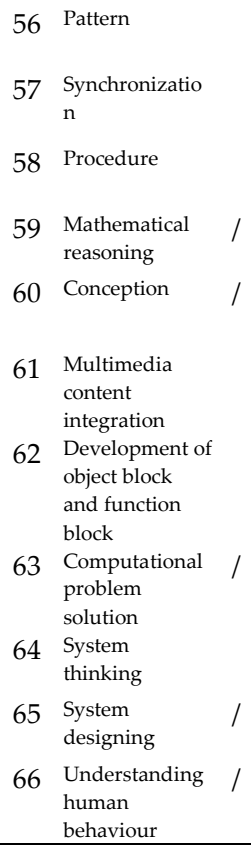

\section{Conclusion and Recommendations}

The frequency of 66 elements of computational thinking that was found via systematic literature review shows that the selection of elements and components that can characterise computational thinking is still wide open. Due to wide-open gaps, there is an attempt to define computational thinking from the context or dimension of concept, practice, and perspectives (Brennan \& Resnick, 2012). Seven computational concepts are sequences, loops, parallelism, events, conditionals, operators, and data structures/variables (Basu et al., 2016; Brennan \& Resnick, 2012; Tsarava et al., 2017). These concepts are also known as the elements of computational thinking skills (Basu et. al, 2016). While computational practices or activities are referring to being incremental, reusing and remixing, testing and debugging, and modularizing and abstracting (Basu et al., 2016). All of these activities occur during the programming process. Furthermore, computational perspectives are referring to expressing, connecting, questioning, the potential study and career path in computing and so on (Basu et. al, 2016).

On the other hand, the finding from systematic literature review consistent with Sondakh (2018), Wing (2006), Turchi and Malizia (2016), and Ota et al. (2016) where a consensus on the elements that able to characterise computational thinking skills can be made. Those elements are abstraction, algorithm, and decomposition. In order to promote these skills including parallelism and pattern generalisation (Burke et. al, 2019) among students of educational programmes, a specific learning approach through module is recommended to be designed with practical programming skill activities involving sequences, loops, parallelism, events, conditions, operators and data structures (Basu et. al, 2016). In conclusion, Table 3 shows the relationship between programming skills by Basu et. al (2016) and computational thinking skills by Burke et. al (2019) based on three dimensions of computational thinking by Brennan and Resnick (2012). 
Table 3: Relationship between programming skills and three-dimensional computational thinking

\begin{tabular}{|c|c|c|}
\hline Dimension & Programming Skills & Computational Thinking Skills \\
\hline $\begin{array}{l}\text { Computational } \\
\text { concept (element) }\end{array}$ & $\begin{array}{l}\text { Sequences, loops, parallelism, } \\
\text { events, conditions, operators, } \\
\text { and data structures, These } \\
\text { elements are found in } \\
\text { programming language. }\end{array}$ & $\begin{array}{l}\text { Algorithmic thinking, decomposition, } \\
\text { abstraction, parallelism, and pattern } \\
\text { generalization. }\end{array}$ \\
\hline $\begin{array}{l}\text { Computational } \\
\text { practice (activity) }\end{array}$ & $\begin{array}{l}\text { Being incremental, reusing and } \\
\text { remixing, testing and } \\
\text { debugging, modularization, } \\
\text { and abstraction. these activities } \\
\text { occur during programming } \\
\text { process. }\end{array}$ & $\begin{array}{l}\text { Collecting and arranging data, designing } \\
\text { and remixing computational model, } \\
\text { debugging simulation, documenting } \\
\text { one's work, and decompose complex } \\
\text { problem into needed sections } \\
\text { collaboratively. }\end{array}$ \\
\hline $\begin{array}{l}\text { Computational } \\
\text { perspective }\end{array}$ & $\begin{array}{l}\text { Expression, } \begin{array}{r}\text { connecting, } \\
\text { questioning, potential }\end{array} \\
\text { education, and career paths } \\
\text { specific in computing field. }\end{array}$ & $\begin{array}{l}\text { The perspectives that students form about } \\
\text { the world around them and relate to them } \\
\text { after they understand these concepts in } \\
\text { each practice. The perspective here is } \\
\text { referring to the pupil/student perception } \\
\text { towards the fluency of technology, and an } \\
\text { appreciation on how system works, why } \\
\text { it is broken down, and how it can be } \\
\text { improved. }\end{array}$ \\
\hline
\end{tabular}

\section{References}

Altanis, I., Retalis, S., \& Petropoulou, O. (2018). Systematic design and rapid development of motion-based touchless games for enhancing students' thinking skills. Education Sciences, 8(1), 1-15. https://doi.org/10.3390/educsci8010018

Angeli, C., Voogt, J., Fluck, A., Webb, M., Cox, M., Malyn-Smith, J., et al. (2016). A K-6 computational thinking curriculum framework: Implications for teacher knowledge. Journal of Educational Technology \& Society, 19(3), 47-57.

Araujo, A. L. S. O., Santos, J. S., Andrade, W. L., Guerrero, D. D. S., \& Dagiene, V. (2017). Exploring computational thinking assessment in introductory programming courses. In C. Dyer (Ed.), Proceedings of the 2017 IEEE Frontiers in Education Conference (pp. 1-9). Institute of Electrical and Electronics Engineers. https://doi.org/10.1109/FIE.2017.8190652

Arraki, K., Blair, K., Bürgert, T., Greenling, J., Haebe, J., Lee, G., et al. (2014). DISSECT: An experiment in infusing computational thinking in K-12 science curricula. In IEEE (Ed), Proceedings of the 2014 IEEE Frontiers in Education Conference. (pp. 1-9). Institute of Electrical and Electronics Engineers. https://doi.org/10.1109/FIE.2014.7044262

Atmatzidou, S., \& Demetriadis, S. (2016). Advancing students' computational thinking skills through educational robotics: A study on age and gender relevant differences. Robotics and Autonomous Systems, 75, 661-670. https://doi.org/10.1016/j.robot.2015.10.008

Barr, V., \& Stephenson, C. (2011). Bringing computational thinking to K-12: what is Involved and what is the role of the computer science education community? ACM Inroads, 2(1), 48-54. https://doi.org/10.1145/1929887.1929905

Basogain, X., Olabe, M. A., Olabe, J. C., Ramírez, R., Del Rosario, M., \& Garcia, J. (2016). PC-01: Introduction to computational thinking: Educational technology in primary and secondary education. In F. J. García-Peñalvo and A. J. Mendes (Eds.), Proceedings of the 2016 International Symposium on Computers in Education (pp. 1-5). Institute of Electrical and Electronics Engineers. https://doi.org/10.1109/SIIE.2016.7751816

Basu, S., Mustafara, E., \& Rich, K. (2016). CIRCL Primer: Computational Thinking. In CIRCL Primer Series. Center for Innovative Research in Cyberlearning. http://circlcenter.org/computational-thinking

Brennan, K., \& Resnick, M. (2012). New frameworks for studying and assessing the development of computational thinking. Massachusetts Institute of Technology. https://www.media.mit.edu/publications/newframeworks-for-studying-and-assessing-the- development-of-computational-thinking/

Burke, Q., Bailey, C. S., \& Ruiz, P. (2019). CIRCL Primer: Assessing Computational Thinking. In CIRCL Primer Series. Center for Innovative Research in Cyberlearning. https://circlcenter.org/assessing-computationalthinking. 
Cross, J., Hamner, E., Zito, L., \& Nourbakhsh, I. (2016). Engineering and computational thinking talent in middle school students: a framework for defining and recognizing student affinities. In IEEE (Ed.), Proceedings of the 2016 IEEE Frontiers in Education Conference (pp. 1-9). Institute of Electrical and Electronics Engineers. https://doi.org/10.1109/FIE.2016.7757720

Curriculum Development Division. (2015). Dokumen Standard Kurikulum dan Pentaksiran Asas Sains Komputer Tingkatan 1. Ministry of Education Malaysia.

de Araujo, A. L. S. O., Andrade, W. L., \& Guerrero, D. D. S. (2016). A systematic mapping study on assessing computational thinking abilities. In IEEE (Ed.), Proceedings of the 2016 IEEE Frontiers in Conference (pp. 1-9). Institute of Electrical and Electronics https://doi.org/10.1109/FIE.2016.7757678

Geck, C. S, Hooi, Y. K., Mohamad, Z., \& Ismail, F. (2016). Sains Komputer Tingkatan 4. Oxford Fajar Sdn. Bhd.

Google for Education. (n.d.). Exploring Computational Thinking. https://edu.google.com/resources/programs/exploring-computational-thinking/\#!ct-overview

Grover, S., \& Pea, R. (2013). Computational thinking in K-12: A review of the state of the field. Educational Researcher, 42(1), 38-43. https://doi.org/10.3102/0013189X12463051

Heintz, F., Mannila, L., \& Färnqvist, T. (2016). A review of models for introducing computational thinking, computer science and computing in K-12 education. In IEEE (Ed.), Proceedings of the 2016 Frontiers in Education Conference (pp. 1-9). Institute of Electrical and Electronics Engineers. https://doi.org/10.1109/FIE.2016.7757410

Ioannidou, A., Bennett, V., Repenning, A., Koh, K. H., \& Basawapatna, A. (2011, April 8). Computational Thinking Patterns [Paper presentation]. Annual Meeting of the American Educational Research Association (AERA) in the Division C - Learning and Instruction/Section 7: Technology Research Symposium "Merging Human Creativity and the Power of Technology: Computational Thinking in the K-12 Classroom", Colorado. https://files.eric.ed.gov/fulltext/ED520742.pdf

Kalelioglu, F., Gülbahar, Y., \& Kukul, V. (2016). A Framework for Computational Thinking Based on a Systematic Research Review. Baltic Journal of Modern Computing, 4(3), 583-596.

Kassan, S., Fatt, L. K., \& Meng, T. Y. (2016). Asas Sains Komputer Tingkatan 1. Percetakan Rina Sdn. Bhd.

Kong, R., \& Wong, G. K. W. (2017). Teachers' Perception of Professional Development in Coding Education. In IEEE (Ed.), Proceedings of the 2017 IEEE 6th International Conference on Teaching, Assessment, and Learning for Engineering (pp. 377-380). Institute of Electrical and Electronics Engineers. https://doi.org/10.1109/TALE.2017.8252365

Korkmaz, Ö., Çakir, R., \& Özden, M. Y. (2017). A validity and reliability study of the computational thinking scales (CTS). Computers in Human Behavior, 72(2017), 558-569. https://doi.org/10.1016/j.chb.2017.01.005

Kotini, I., \& Tzelepi, S. (2015). A gamification-based framework for developing learning activities of computational thinking. In T. Reiners, \& L. Wood (Eds.), Gamification in Education and Business (pp. 219-252). Springer, Cham. https://doi.org/10.1007/978-3-319-10208-5_12

Li, Y. (2016). Teaching programming based on Computational Thinking. In IEEE (Ed.), Proceedings of the 2016 IEEE Frontiers in Education Conference (pp. 1-7). Institute of Electrical and Electronics Engineers. https://doi.org/10.1109/FIE.2016.7757408

Lowe, T., \& Brophy, S. (2017). An operationalized model for defining computational thinking. Frontiers in Education 2017, 1( ), 1-8. https://doi.org/10.1109/FIE.2017.8190682

Lugo, M. J. R., Olabe, X. B., \& Niño, N. M. (2018). "Evolution": Design and Implementation of Digital Educational Material to Strengthen Computational Thinking Skills. In IEEE (Ed.), Proceedings of the IEEE Revista Iberoamericana de Tecnologias del Aprendizaje (pp. 37-45). Institute of Electrical and Electronics Engineers. https://doi.org/10.1109/RITA.2018.2809943

Lye, S. Y., \& Koh, J. H. L. (2014). Review on teaching and learning of computational thinking through programming: What is next for K-12? Computers in Human Behavior, 41(2014), 51-61. https://doi.org/10.1016/j.chb.2014.09.012

Ministry of Education Malaysia. (2017). Ministry of Education's Ikhtisas Circular Letter Number 9 Year 2016: Pelaksanaan Kurikulum Standard Sekolah Menengah Secara Berperingkat-peringkat Mulai Tahun 2017. https://www.moe.gov.my/images/pekeliling/2016/circularfile_file_001420.pdf

Moreno-León, J., Robles, G., \& Román-González, M. (2015). Dr. Scratch: Automatic analysis of scratch projects to assess and foster computational thinking. RED-Revista de Educación a Distancia, (46), 1-23. https://doi.org/10.6018/red/46/10

National Research Council. (2010). Report of a workshop on the scope and nature of computational thinking. National Academies Press. 
Ota, G., Morimoto, Y., \& Kato, H. (2016). Ninja code village for scratch: Function samples/function analyzer and automatic assessment of computational thinking concepts. In A. Blackwell, B. Plimmer, \& G. Stapleton (Eds.), 2016 Proceedings of the IEEE Symposium on Visual Languages and Human-Centric Computing (pp. 238-239). Institute of Electrical and Electronics Engineers. http://doi.org/10.1109/VLHCC.2016.7739695

Papert, S. (1980). Mindstorms: Children, computers, and powerful ideas. Basic Books Inc.

Repenning, A., Basawapatna, A., \& Escherle, N. (2016). Computational thinking tools. In A. Blackwell, B. Plimmer, \& G. Stapleton (Eds.), Proceedings of the 2016 IEEE Symposium on Visual Languages and Human-Centric Computing (pp. 218-222). Institute of Electrical and Electronics Engineers. https://doi.org/10.1109/VLHCC.2016.7739688

Seiter, L., \& Foreman, B. (2013). Modeling the learning progressions of computational thinking of primary grade students. In ACM (Ed.), Proceedings of the ninth annual international ACM conference on International computing education research (pp.59-66). Association for Computing Machinery. https://doi.org/10.1145/2493394.2493403

Shute, V. J., Sun C., \& Asbell-Clarke, J. (2017). Demystifying computational thinking. Educational Research Review, 22(2017), 142-158. https://doi.org/10.1016/j.edurev.2017.09.003

Silva, L. R., da Silva, A. P., Toda, A., \& Isotani, S. (2018). Impact of Teaching Approaches to Computational Thinking on High School Students: A Systematic Mapping. In M. Chang et al. Proceedings of the 2018 IEEE 18th International Conference on Advanced Learning Technologies (pp. 285-289). Institute of Electrical and Electronics Engineers. https://doi.org/ 10.1109/ICALT.2018.00072

Sondakh, D. E, (2018). Review of Computational Thinking Assessment in Higher Education. http://doi.org/10.13140/RG.2.2.16120.55042

The Computer Science Teachers Association \& International Society for Technology in Education. (2011). Operational Definition of Computational Thinking for $K-12$ Education. https://id.iste.org/docs/ctdocuments/computational-thinking-operational-definition-flyer.pdf

Toedte, R. J., \& Aydeniz, M. (2015). Computational thinking and impacts on K-12 science education. In IEEE (Ed.), Proceedings of the 2015 IEEE Frontiers in Education Conference (pp. 1-7). Institute of Electrical and Electronics Engineers. https://doi.org/10.1109/FIE.2015.7344239

Tsarava, K., Moeller, K., \& Ninaus, M. (2018). Training Computational Thinking through board games: The case of Crabs \& Turtles. International Journal of Serious Games, 5(2), 25-44. https://doi.org/10.17083/ijsg.v5i2.248

Tsarava, K., Moeller, K., Pinkwart, N., Butz, M., Trautwein, U., \& Ninaus, M. (2017). Training computational thinking: Game-based unplugged and plugged-in activities in primary school. In M. Pivec \& J. Grundler (Eds.), Proceedings of the 11th European Conference on Games Based Learning (pp. 687-695). ACPI.

Turchi, T., \& Malizia, A. (2016). Fostering computational thinking skills with a tangible blocks programming environment. In A. Blackwell, B. Plimmer, and G. Stapleton (Eds.), Proceedings of the 2016 IEEE Symposium on Visual Languages and Human-Centric Computing (pp. 232-233). Institute of Electrical and Electronics Engineers. http://doi.org/10.1109/VLHCC.2016.7739692

Vallance, M., \& Towndrow, P. A. (2016). Pedagogic transformation, student-directed design and computational thinking. Pedagogies: An International Journal, 11(3), 218-234. https://doi.org/10.1080/1554480X.2016.1182437

Wang, D., Wang, T., \& Liu, Z. (2014). A tangible programming tool for children to cultivate computational thinking. The Scientific World Journal, 2014(), 1-10. http://doi.org/10.1155/2014/428080

Weintrop, D., Beheshti, E., Horn, M., Orton, K., Jona, K., Trouille, L., \& Wilensky, U. (2016). Defining computational thinking for mathematics and science classrooms. Journal of Science Education and Technology, 25(1), 127-147. https://doi.org/10.1007/s10956-015-9581-5

Wing, J. M. (2006). Computational Thinking. Communications of the ACM, 49(3), 33-35. https://doi.org/10.1145/1118178.1118215

Worrell, B., Brand, C., \& Repenning, A. (2015). Collaboration and Computational Thinking: A classroom structure. In Z. Li, C. Ermel, and S. D. Fleming (Eds.), Proceedings of the 2015 IEEE Symposium on Visual Languages and Human-Centric Computing (VLHCC) (pp. 183-187). Institute of Electrical and Electronics Engineers. https://doi.org/10.1109/VLHCC.2015.7357215

Yadav, A., Mayfield, C., Zhou, N., Hambrusch, S., \& Korb, J. T. (2014). Computational thinking in elementary and secondary teacher education. ACM Transactions on Computing Education, 14(1), 1-16. https://doi.org/10.1145/2576872

Yadav, A., Zhou, N., Mayfield, C., Hambrusch, S., \& Korb, J. T. (2011). Introducing computational thinking in education courses. In ACM (Ed.), Proceedings of the 42nd ACM technical symposium on Computer Science education. Association for Computing Machinery. https://doi.org/10.1145/1953163.1953297 